\title{
Association of High Density Lipoprotein Cholesterol with Renal Function in Type 2 Diabetic Subjects in a Bangladeshi Population
}

\author{
Muhammad Saiedullah ${ }^{1}$, Muhammad Rezwanur Rahman ${ }^{2}$, Shahnaj Begum ${ }^{1}$, Shoma Hayat ${ }^{3}$, \\ Md. Aminul Haque Khan ${ }^{4}$
}

\begin{abstract}
Background: Abnormalities in lipid metabolism are associated with renal diseases. Association of serum lipid parameters with renal function is less studied in subjects with type 2 diabetes in Bangladeshi population. Objective: To assess the correlation of high density lipoprotein cholesterol with glomerular filtration rate (GFR) in type 2 diabetic subjects. Materials and Methods: One thousand three hundred thirty confirmed diabetic subjects advised for $H b A_{1 c}$, serum creatinine, serum total cholesterol, serum triglycerides, serum $H D L$ cholesterol and LDL cholesterol were included in the study. Serum total cholesterol, HDL cholesterol, triglyceride, serum creatinine, $H b A_{l c}$ were measured by standard methods and serum LDL cholesterol was calculated by Friedewald's formula. GFR was calculated by MDRD4 variables prediction equation. Total subjects were grouped according to sex; both males and females were subdivided into three subgroups depending on GFR values. Results of lipid parameters were compared by one-way ANOVA among different groups and correlation of lipid parameters with GFR were expressed by Pearson r. Results: HDL cholesterol was significantly different among different GFR groups $(p<0.05)$ and positively correlated with GFR $(r=0.1386, p<0.001)$ in males. Total cholesterol and LDL cholesterol showed feeble positive correlation with GFR $(r=0.0789, p<0.05$ for total cholesterol and $r=0.0768$, $p<0.05$ for $L D L$ cholesterol), but are not significantly different among GFR groups ( $p>0.05)$ in males. Total cholesterol, HDL cholesterol, LDL cholesterol, non-HDL cholesterol and LDL$C / H D L-C$ were significantly different among three different GFR groups $(p<0.01)$ and only $H D L$ cholesterol and LDL-C/HDL-C showed weak correlation with GFR ( $r=0.0770, p<0.05$ for HDL cholesterol and $r=-0.0803, p<0.05$ for $L D L-C / H D L-C)$ in females. Conclusion: The study revealed that HDL cholesterol was significantly and positively correlated with glomerular filtration rate in both male and female diabetic subjects and assessment of lipid parameters might be a helpful tool to prevent or delay the progression of renal insufficiency.
\end{abstract}

Key words: Type 2 diabetes, Glomerular filtration rate, Serum lipid parameters

J Enam Med Col 2012; 2(1): 15-19

\section{Introduction}

Abnormalities in lipid metabolism are associated with renal diseases in both diabetic and non-diabetic subjects. There is an inverse association of serum lipids with renal function. ${ }^{1,2}$ Lipid associated renal

dysfunction may be mediated by tubulointerstitial inflammation, foam cell formation and tissue injury ${ }^{3,4}$, matrix production and glomerulosclerosis due to accumulation of native and oxidized low-

1. Senior Scientific Officer, Department of Clinical Biochemistry, Bangladesh Institute of Health Sciences, Dhaka

2. Associate Professor, Department of Biochemistry, Delta Medical College, Dhaka

3. Scientific Officer, Department of Clinical Biochemistry, Bangladesh Institute of Health Sciences, Dhaka

4. Professor, Department of Biochemistry, Enam Medical College, Savar, Dhaka

Correspondence Muhammad Saiedullah,Email:md.saiedullah@gmail.com 
density lipoprotein (LDL) in glomerular mesangium. ${ }^{5-7}$ Low plasma high-density lipoprotein (HDL) has been identified as an independent risk factor for progression of renal disease. ${ }^{8,9}$ Animal studies showed that consumption of lipid-rich diet exacerbates and correction of hyperlipidemia attenuates the severity of glomerulosclerosis and tubulointerstitial fibrosis $\mathrm{s}^{3,6,10-12}$ and normalization of HDL metabolism without changing serum total cholesterol retards the progression of renal disease in $5 / 6$ nephrectomized rats. ${ }^{13}$ Studies on animal models of hyperlipidemia including apo-lipoprotein E knockout (apo E-KO) mice and Otsuka Long Evans Tokushima Fatty (OLETF) rats have also suggested the association of hyperlipidemia with the development of early renal lesions. ${ }^{14,15}$ Moreover, HDL serves as a potent endogenous inhibitor of inflammation, platelet adhesion and LDL oxidation. ${ }^{16}$ Since type 2 diabetes is recognized as an inflammatory condition associated with insulin resistance ${ }^{17}$ and abnormal endothelial vascular reactivity ${ }^{18}$, HDL particles may partly play role to prevent progression of renal injury. We conducted this study to evaluate the relationship of lipid parameters, particularly HDL cholesterol with GFR in type 2 diabetic subjects in a Bangladeshi population.

\section{Materials and Methods}

This cross sectional study was carried out in the Department of Clinical Biochemistry, Bangladesh Institute of Health Sciences, Dhaka during July 2010 to August 2010. One thousand three hundred thirty specimens of confirmed diabetic subjects, both males and females, advised for $\mathrm{HbA}_{1 \mathrm{c}}$, serum creatinine, serum total cholesterol, serum triglycerides, serum HDL cholesterol and LDL cholesterol were included for the study. $\mathrm{HbA}_{1 \mathrm{c}}$ was measured by HPLC based automated analyzer D-10 ${ }^{\mathrm{TM}}$ (Bio-Rad, USA), serum creatinine was measured by modified Jaffe's method using Dimension RxL Max (Siemens Health Care Ltd.). Serum total cholesterol, serum triglyceride and serum HDL cholesterol concentrations were measured by kits manufactured by Siemens Health Care Ltd. using Dimension RxL Max automated analyzer. Serum LDL cholesterol was calculated by Friedewald's formula ${ }^{19}$ and eGFR was calculated using the simplified MDRD4 equation. ${ }^{20}$ Subjects were grouped according to sex, both males and females were subdivided into three groups depending 16 to eGFR (Group-I, eGFR $<60 \mathrm{~mL} / \mathrm{min} / 1.73 \mathrm{~m}^{2}$ for males, eGFR $<55 \mathrm{~mL} / \mathrm{min} / 1.73 \mathrm{~m}^{2}$ for females; Group-II, eGFR $60-89 \mathrm{~mL} / \mathrm{min} / 1.73 \mathrm{~m}^{2}$ for males, eGFR $55-85 \mathrm{~mL} / \mathrm{min} / 1.73 \mathrm{~m}^{2}$ for females and GroupIII, eGFR $>89 \mathrm{~mL} / \mathrm{min} / 1.73 \mathrm{~m}^{2}$ for males, eGFR $>$ $85 \mathrm{~mL} / \mathrm{min} / 1.73 \mathrm{~m}^{2}$ for females). Results are expressed as mean $\pm \mathrm{SD}$ and correlation of lipid parameters with eGFR were done by Statsoft STATISTICA version 8 for windows in the total study subjects, in male and female subjects and compared by GraphPad Prism version 5.03 for windows.

\section{Results}

The mean \pm SD of age of the total study subjects was $50.12 \pm 11.65$ years. Of the total study subjects 653 (49\%) were males and 677 (51\%) were females. In the total population mean $\pm \mathrm{SD}$ of $\mathrm{HbA}_{1 \mathrm{c}}$, serum total cholesterol, serum triglycerides, serum HDL cholesterol, serum LDL cholesterol, non-HDL cholesterol, serum creatinine and estimated GFR were $9.28 \pm 2.43 \%, 186.93 \pm 44.04 \mathrm{mg} / \mathrm{dL}, 200.38 \pm$ $147.5 \mathrm{mg} / \mathrm{dL}, 38.48 \pm 8.28 \mathrm{mg} / \mathrm{dL}, 110.26 \pm 37.13$ $\mathrm{mg} / \mathrm{dL}, 148.24 \pm 42.89 \mathrm{mg} / \mathrm{dL}, 0.99 \pm 0.28 \mathrm{mg} / \mathrm{dL}$ and $79.5 \pm 20.98 \mathrm{~mL} / \mathrm{min} / 1.73 \mathrm{~m}^{2}$ respectively. In the total study population eGFR significantly correlated with age $(\mathrm{r}=-0.5076, \mathrm{p}<0.0001)$, HDL cholesterol $(\mathrm{r}=0.0669, \mathrm{p}<0.05)$ but not with $\mathrm{HbA}_{1 \mathrm{c}}(\mathrm{r}=0.0400$, $\mathrm{p}>0.05)$, total cholesterol $(\mathrm{r}=0.0015, \mathrm{p}>0.05)$, triglycerides $(\mathrm{r}=-0.0199, \mathrm{p}>0.05)$, LDL cholesterol $(\mathrm{r}=0.0134, \mathrm{p}>0.05)$, non-HDLcholesterol $(\mathrm{r}=-0.0115$, $\mathrm{p}>0.05)$ and LDL-C/HDL-C $(r=-0.0313, \mathrm{p}>0.05)$. Comparison of different variables between males and females are shown in Table I. Serum total cholesterol, serum HDL cholesterol, serum LDL cholesterol were significantly higher in females than males (Table I) and serum triglyceride, serum LDLC/HDL-C, serum creatinine and eGFR were significantly lower in females than in males (Table I). No statistically significant difference was observed for age, $\mathrm{HbA}_{1 \mathrm{c}}$ and non-HDL cholesterol between males and females.

Comparison of lipid parameters among the three predefined eGFR groups is shown in Table II. One way ANOVA showed that only HDL cholesterol was significantly different among three eGFR groups in male diabetic subjects (Fig 1A) and total cholesterol, HDL cholesterol (Fig 1B), LDL cholesterol, non- 
HDL cholesterol and LDL-C/HDL-C were significantly different among different eGFR groups in female diabetic subjects (Table II).

The correlation coefficient of age, $\mathrm{HbA}_{1 \mathrm{c}}$ and lipid parameters with GFR is presented in Table III. The correlation coefficients of total cholesterol, HDL cholesterol and LDL cholesterol are statistically signi- ficant with eGFR in male diabetic subjects and correlation coefficients of HDL cholesterol and LDL-C/HDL-C are statistically significant with eGFR in female diabetic subjects (Table III). The correlation coefficient of HDL cholesterol is statistically significant in the total study population, and also in male and female diabetic subjects.

Table I: Comparison of different variables between male and female diabetic subjects

\begin{tabular}{|c|c|c|c|c|}
\hline Variables & $\begin{array}{c}\text { Male } \\
(\mathrm{n}=653)\end{array}$ & $\begin{array}{c}\text { Female } \\
(\mathrm{n}=677)\end{array}$ & $\mathrm{t}$ values & $\mathrm{p}$ values \\
\hline $\operatorname{Sex}(\%)$ & 49 & 51 & & \\
\hline Age (years) & $50.47 \pm 11.40$ & $49.78 \pm 11.89$ & 1.094 & 0.2744 \\
\hline $\mathrm{HbA1c}(\%)$ & $9.33 \pm 2.46$ & $9.23 \pm 2.40$ & 0.7443 & 0.4568 \\
\hline Serum total cholesterol (mg/dL) & $182.3 \pm 42.58$ & $191.4 \pm 44.97$ & 3.815 & 0.001 \\
\hline Serum triglycerides (mg/dL) & $208.7 \pm 167.8$ & $192.4 \pm 124.5$ & 2.011 & 0.0446 \\
\hline Serum HDL cholesterol (mg/dL) & $36.00 \pm 7.12$ & $40.86 \pm 8.63$ & 11.18 & $<0.0001$ \\
\hline Serum LDL cholesterol (mg/dL) & $107.1 \pm 36.14$ & $113.3 \pm 37.84$ & 3.062 & 0.0022 \\
\hline Serum non-HDL cholesterol (mg/dL) & $146.3 \pm 41.71$ & $150.1 \pm 43.93$ & 1.646 & 0.1001 \\
\hline Serum LDL-C/HDL-C & $3.05 \pm 1.08$ & $2.85 \pm 1.00$ & 3.556 & 0.0004 \\
\hline Serum creatinine $(\mathrm{mg} / \mathrm{dL})$ & $1.08 \pm 0.25$ & $0.90 \pm 0.28$ & 12.10 & $<0.0001$ \\
\hline eGFR (ml/min/1.73m²) & $81.74 \pm 19.49$ & $77.35 \pm 22.12$ & 3.838 & 0.0001 \\
\hline
\end{tabular}

Table II: Comparison of lipid parameters among different GFR groups in male and female diabetic subjects

\begin{tabular}{|c|c|c|c|c|c|}
\hline Parameters & Sex & Group-I & Group-II & Group-III & $\mathrm{p}$ values \\
\hline $\begin{array}{l}\text { Serum total cholesterol } \\
(\mathrm{mg} / \mathrm{dL})\end{array}$ & $\begin{array}{l}\text { Male } \\
\text { Female }\end{array}$ & $\begin{array}{l}177.7 \pm 39.54 \\
182.7 \pm 45.61\end{array}$ & $\begin{array}{l}181.3 \pm 41.92 \\
192.8 \pm 47.24\end{array}$ & $\begin{array}{l}185.9 \pm 44.87 \\
185.3 \pm 39.47\end{array}$ & $\begin{array}{l}0.2686 \\
0.0003\end{array}$ \\
\hline $\begin{array}{l}\text { Serum triglycerides } \\
(\mathrm{mg} / \mathrm{dL})\end{array}$ & $\begin{array}{l}\text { Male } \\
\text { Female }\end{array}$ & $\begin{array}{l}205.9 \pm 100.4 \\
195.9 \pm 97.58\end{array}$ & $\begin{array}{l}203.9 \pm 131.7 \\
198.4 \pm 107.2\end{array}$ & $\begin{array}{l}218.5 \pm 235.9 \\
181.7 \pm 155.8\end{array}$ & $\begin{array}{l}0.6042 \\
0.2784\end{array}$ \\
\hline $\begin{array}{l}\text { Serum HDL cholesterol } \\
(\mathrm{mg} / \mathrm{dL})\end{array}$ & $\begin{array}{l}\text { Male } \\
\text { Female }\end{array}$ & $\begin{array}{l}34.13 \pm 6.42 \\
37.64 \pm 9.03\end{array}$ & $\begin{array}{l}35.80 \pm 7.04 \\
41.49 \pm 8.40\end{array}$ & $\begin{array}{l}37.15 \pm 7.37 \\
41.38 \pm 8.48\end{array}$ & $\begin{array}{l}0.0032 \\
0.0002\end{array}$ \\
\hline $\begin{array}{l}\text { Serum LDL cholesterol } \\
(\mathrm{mg} / \mathrm{dL})\end{array}$ & $\begin{array}{l}\text { Male } \\
\text { Female }\end{array}$ & $\begin{array}{l}103.9 \pm 36.38 \\
106.1 \pm 38.47\end{array}$ & $\begin{array}{l}106.7 \pm 35.47 \\
118.3 \pm 39.94\end{array}$ & $\begin{array}{l}109.1 \pm 37.31 \\
109.2 \pm 33.14\end{array}$ & $\begin{array}{l}0.5221 \\
0.0019\end{array}$ \\
\hline $\begin{array}{l}\text { Serum non-HDL } \\
\text { cholesterol }(\mathrm{mg} / \mathrm{dL})\end{array}$ & $\begin{array}{l}\text { Male } \\
\text { Female }\end{array}$ & $\begin{array}{l}143.6 \pm 39.63 \\
145.1 \pm 44.87\end{array}$ & $\begin{array}{l}145.5 \pm 41.04 \\
156.7 \pm 45.23\end{array}$ & $\begin{array}{l}148.8 \pm 43.82 \\
143.9 \pm 37.92\end{array}$ & $\begin{array}{l}0.5514 \\
0.0009\end{array}$ \\
\hline Serum LDL-C/HDL-C & $\begin{array}{l}\text { Male } \\
\text { Female }\end{array}$ & $\begin{array}{l}3.14 \pm 1.18 \\
2.95 \pm 1.23\end{array}$ & $\begin{array}{l}3.06 \pm 1.07 \\
2.91 \pm 1.01\end{array}$ & $\begin{array}{l}3.01 \pm 1.06 \\
2.71 \pm 0.89\end{array}$ & $\begin{array}{l}0.6194 \\
0.0298\end{array}$ \\
\hline
\end{tabular}


Table III: Correlation of age, HbAlc and lipid parameters with GFR in males and females

$\begin{array}{lccc}\text { Variables } & \text { Male } & \text { Female } \\ \text { Age } & -0.4769^{* * *} & -0.5443^{* * *} \\ \text { HbA1c } & 0.0672^{\mathrm{NS}} & 0.0127^{\mathrm{NS}} \\ \text { Serum total cholesterol } & 0.0789^{*} & -0.0410^{\mathrm{NS}} \\ \text { Serum triglycerides } & -0.0019^{\mathrm{NS}} & -0.0542^{\mathrm{NS}} \\ \text { Serum HDL cholesterol } & 0.1386^{* * *} & 0.0770^{*} \\ \text { Serum LDL cholesterol } & 0.0768^{*} & -0.0217^{\mathrm{NS}} \\ \text { Serum non-HDL cholesterol } & 0.0569^{\mathrm{NS}} & -0.0580^{\mathrm{NS}} \\ \text { Serum LDL-C/HDL-C } & 0.0001^{\mathrm{NS}} & -0.0803^{*}\end{array}$

$*, p<0.05 ;{ }^{* *}, \mathrm{p}<0.01 ; * * *, \mathrm{p}<0.001 ; \mathrm{NS}$, Not significant
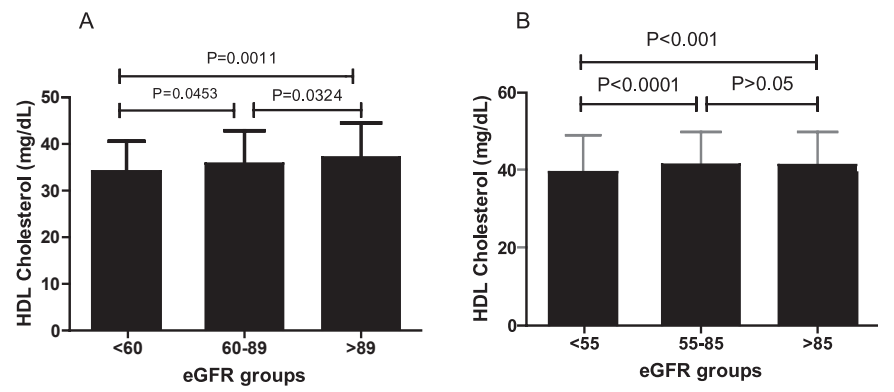

Fig 1. Comparison of HDL cholesterol among different GFR groups in males (A) and in females (B) [eGFR is expressed in $\mathrm{mL} / \mathrm{min} / 1.73 \mathrm{~m}^{2}$ ]

\section{Discussion}

In this study on diabetic subjects we observed significant differences of all lipid parameters except non-HDL cholesterol between males and females. Serum creatinine and eGFR were also significantly different between males and females. So we analyzed the association of lipid parameters with eGFR in male and female diabetic subjects separately.

In male diabetic subjects only serum HDL cholesterol was significantly different among different eGFR groups and showed positive association with eGFR. Though serum total cholesterol and LDL cholesterol showed weak but statistically significant positive association with eGFR, these were not significantly different among different eGFR groups. Moreover, nonHDL cholesterol was neither significantly different in different eGFR groups nor significantly associated with eGFR. No statistically significant association was observed for serum triglycerides and LDL-C/HDL-C with eGFR.
In female diabetic subjects, the correlation coefficients of serum total cholesterol, serum triglycerides, serum LDL cholesterol and serum non-HDL cholesterol with eGFR were not statistically significant, but serum HDL cholesterol and serum LDL-C/HDL-C showed statistically significant positive association with eGFR. Though serum total cholesterol, serum LDL cholesterol, non-HDL cholesterol and LDLC/HDL-C were significantly different among different eGFR groups, these were not significantly different between subjects with eGFR $>85 \mathrm{~mL} / \mathrm{min} / 1.73 \mathrm{~m}^{2}$ and subjects with eGFR $<55 \mathrm{~mL} / \mathrm{min} / 1.73 \mathrm{~m}^{2}$ (Table II). Only HDL cholesterol was significantly lower in subjects with eGFR $<55 \mathrm{~mL} / \mathrm{min} / 1.73 \mathrm{~m}^{2}$ than $\mathrm{HDL}$ cholesterol in subjects with eGFR 55-84 $\mathrm{mL} / \mathrm{min} / 1.73 \mathrm{~m}^{2}$ and eGFR $>85 \mathrm{~mL} / \mathrm{min} / 1.73 \mathrm{~m}^{2}$. In different studies lipid parameters revealed different association with GFR. Krikken et $\mathrm{al}^{21}$ showed that an inverse weak association exists between HDL cholesterol and GFR in nondiabetic subjects without kidney disease and Lin et $\mathrm{al}^{22}$ found no association between lipid parameters and eGFR in female diabetic subjects. Kim et $\mathrm{al}^{23}$ and Lin et $\mathrm{al}^{24}$ showed that total cholesterol, triglycerides, LDL cholesterol and non-HDL cholesterol were inversely associated with eGFR. Lin et $\mathrm{al}^{24}$ also showed that serum HDL cholesterol was positively associated with eGFR in male diabetic subjects. Our results are partly consistent with the study of Lin et $\mathrm{al}^{24}$ and we found that positive association of serum HDL cholesterol with GFR is stronger in males than in females. From our study we can conclude, though traditional lipid parameters are not sufficient to explore the association of lipid parameters with $\mathrm{GFR}^{25}$, still their measurement and assessment may be helpful to prevent the progression of renal insufficiency.

\section{References}

1. Crook ED, Thallapureddy A, Migdal S, Flack JM, Grerne EL, Salahudeen A, Tucker JK, Taylor HA Jr. Lipid abnormalities and renal deasease: is dyslipidemia a predictor of progression of renal disease? Am J Med Sci 2003; 325: 340-348.

2. Abrass CK. Cellular lipid metabolism and the role of lipids in progressive renal disease. Am J Nephrol 2004; 24: 46-53. 
3. Magil AB. Interstitial foam cells and oxidized lipoprotein in human glomerular disease. Mod Pathol 1999; 12: 33-40.

4. Brunskill NJ. Albumin signals the coming of age of proteinuric nephropathy. J Am Soc Nephrol 2004; 15: 504-505.

5. Lee HS, Lee JS, Koh HI, Ko KW. Intraglomerular lipid deposition in routine biopsies. Clin Nephrol 1991; 36: 67-75.

6. Moorhead JF, Wheeler DC, Varghese Z. Glomerular structures and lipids in progressive renal disease. Am J Med 1989; 87:12-20.

7. Wheeler DC, Chana RS. Interactions between lipoproteins, glomerular cells and matrix. Miner Electrolyte Metab 1993; 19: 149-164.

8. Hunsiker LG, Adler S, Caggiula A, England BK, Greene T, Kusek JW, Rogers NL, Teschan PE. Predictors of the progression of renal disease in the Modification of Diet in Renal Disease Study. Kidney Int 1997; 51: 19081919.

9. Schaeffner ES, Kurth T, Curhan GC, Glynn RJ, Rexrode KM, Baigent C, Buring JE, Gaziano JM. Cholesterol and the risk of renal dysfunction in apparently healthy men. J Am Soc Nephrol 2003; 14: 2084-2091.

10. Kasiske BL, O’Donnell MP, Schmitz PG, Keane WF. The role of lipid abnormalities in the pathogenesis of chronic, progressive renal disease. Adv Nephrol Necker Hosp 1991; 20: 109-125.

11. Keane WF. Lipids in progressive renal failure. Wien Klin Wochenschr 1996; 108:420-424.

12. Vazquez-Perez, Aragoncillo P, de Las Heras N, NavarroCid J, Cediel E, Sanz-Rosa D, Ruilope LM, Diaz C, Hernandez G, Lahera V, Cachofeiro V. Atorvastin prevents glomerulosclerosis and renal endothelial dysfunction in hyperlipidemic rabbits. Nephrol Dial Transplant 2001; 16: 40-44.

13. Vaziri ND, Liang K. ACAT inhibition reverses LCAT deficiency and improves plasma HDL in chronic renal failure. Am J Physiol Renal Physiol 2004; 287: 10381043.

14. Wen M, Segerer S, Ddantas M, Brown PA, Hudkins KL, Good-paster T, Kirk E, LeBoeuf RC, Alpers CE. Renal injury in apolipoprotein E-deficient mice. Lab Invest 2002; 82: 999-1006.
15. Sugimoto K, Tsuruoka S, Fujimura A. Effect of enalapril on diabetic nephropathy in OLETF rats: The role of an anti-oxidative action in its protective properties. Clin Exp Pharmacol Physiol 2001; 28: 826-830.

16. Navab M, Berliner JA, Subbanagounder G, Hama S, Lusis AJ, Castellani LW, Reddy S, Shih D, Shi W, Watson AD, Van Lenten BJ, Vora D, Fogelman AM. HDL and the inflammatory response induced by LDLderived oxidized phospholipids. Arterioscler Thromb Vasc Biol 2001; 21: 481-488.

17. Pradhan AD, Manson JE, Rifai N, Buring JE, Ridker PM. C-Reactive protein, interleukin 6 and risk of developing type 2 diabetes mellitus. J Am Med Assoc 2001; 286: 327-334.

18. Skrha J. Pathogenesis of angiopathy in diabetes. Acta Diabetologica 2003; 40: 324-329.

19. Friedewald WT, Levy RI, Fredrickson DS. Estimation of the concentration of low-density lipoprotein cholesterol in plasma without use of the preparative ultracentrifuge. Clin Chem 1972; 18: 499-502.

20. Levy AS, Greene T, Kusek JW, Beck GJ. A simplified equation to predict glomerular filtration rate from serum creatinine (abstract). J Am Soc Nephrol 2000; 11: 155A.

21. Krikken JA, Gansevoort RT, Dullaart RP. The PREVEND Study Group. Lower HDL-C and apolipoprotein A-I are related to higher glomerular filtration rate in subjects without kidney disease. Lipid Res 2010; 51: 1982-1990.

22. Lin J, Hu FB, Mantzoros C, Curhan GC. Lipid and inflammatory biomarkers and kidney function decline in type 2 diabetes. Diabetologia 2010; 53: 263-267.

23. Kim HJ, Jee SH, Lee SJ, Park E, Kim S, Jo JS, Yun JE, Lee GJ. The association of serum lipids with renal function: the Korea Medical Institute Study. Eur J Cardiovasc Prev Rehabil 2009; 16: 60-65.

24. Lin J, Hu FB, Rimm EB, Rifai N, Curhan GC. The association of serum lipids and inflammatory biomarkers with renal function in men with type 2 diabetes mellitus. Kidney Int 2006; 69: 336-342.

25. De Boer IH, Astor BC, Kramer H, Palmas W, Seliger SL, Shlipak MG, Siscovick DS, Tsai MY, Kestenbaum B. Lipoprotein abnormalities associated with mild impairment of kidney function in the multi-ethnic study of atherosclerosis. Clin J Am Soc Nephrol 2008; 3: 125-132. 